\title{
IMPROVEMENT OF GRID-CONNECTED PHOTOVOLTAIC SYSTEM USING ARTIFICIAL NEURAL NETWORK AND GENETIC ALGORITHM UNDER DIFFERENT CONDITION
}

\author{
Alireza Rezvani ${ }^{1 *}$ 'Majid Gandomkar ${ }^{1}$ 'Maziar izadbakhsh ${ }^{1}$ and Saeed Vafaei ${ }^{1}$ \\ ${ }^{1}$ Department of Electrical Engineering, Saveh Branch, Islamic Azad University, Saveh, \\ Iran
}

\begin{abstract}
Photovoltaic (PV) systems have one of the highest potentials and operating ways for generating electrical power by converting solar irradiation directly into the electrical energy. In order to control maximum output power, using maximum power point tracking (MPPT) system is highly recommended. This paper simulates and controls the photovoltaic source by using artificial neural network (ANN) and genetic algorithm (GA) controller. Also, for tracking the maximum point the ANN and GA are used. Data are optimized by GA and then these optimum values are used in neural network training. The simulation results are presented by using Matlab/Simulink and show that the neural network-GA controller of grid-connected mode can meet the need of load easily and have fewer fluctuations around the maximum power point, also it can increase convergence speed to achieve the maximum power point (MPP) rather than conventional method. Moreover, to control both line voltage and current, a grid side $p$ - $q$ controller has been applied.
\end{abstract}

\section{Keywords}

Mppt; neural network; genetic algorithm; controller; Photovoltaic

\section{INTRODUCTION}

Due to harmful consequences of fossil-fuel burning, for electricity production and running out of them (fossil fuel sources), using from solar energy as a clean, inexhaustible and sustainable energy source is indispensable. However, photovoltaic (PV) systems have one of the highest potentials and operating ways for generating electrical power by converting solar irradiation directly into the electrical energy. Although, developing photovoltaic energy sources can reduce fossil fuel dependency, PV panels are low-energy conversion efficient [1,2].

In order to control the maximum output power, using MPPT system is highly recommended. A DC-to-DC converter locates among PV systems and users, which switching opration of this converter is performed by the MPPT [3]. In the last few decades, different methods are utilized in order to achieve maximum power. The most prevalent technics are perturbation and observation algorithm (P\&O) [3, 4] Incremental conductance (IC) [5, 6] fuzzy logic [7, 8] and ANN [9, 11]. According to above mentioned research, the benefits of perturbation and observation algorithm and incremental conductance are1- low cost implementation 2- simple algorithm. And the depletion of these methods is vast fluctuation of output power around the maximum power point 
International Journal of Soft Computing, Mathematics and Control (IJSCMC), Vol. 3, No. 4, November 2014

even under steady state illumination which results in the loss of available energy [12, 13]. However the fast variation of weather condition affects the output and these technics cannot track the maximum power.

Using fuzzy logic can solve the two mentioned problem dramatically. In fact, fuzzy logic controller can reduce the oscillations of output power around the MPPT and has faster respond than P\&O and IC. Furthermore, convergence speed of this way is higher than two mentioned way. One the weak point of fuzzy logic comparing to neural network is oscillations of output power around the maximum power point $[14,15]$. In recent years, artificial intelligence (AI) methods have many applications in defining the size of PV systems, MPPT control and optimal construction of PV systems. In most studies, multilayer perceptron (MLP) neural networks or radial basis function network (RBFN) are used for MPPT controller in photovoltaic systems [16, 17].

ANN based controllers are applied to forecast optimum voltages corresponding to the MPP of PV system for different radiations and temperatures conditions. A review on AI methods applications in renewable energy was studied in these literatures [9, 18]. Neural networks are the best estimation for non-linear systems and by using ANN, oscillations of output power around the MPPT and time to reach the MPP are decreased [6]. In [19-21], GA is used for data optimization and then, the optimum values are utilized for training neural networks and the results show that, the GA technic has less fluctuation in comparison with the conventional methods. However, one of the major drawbacks in mentioned papers that they are not practically connected to the grid in order to ensure the analysis of photovoltaic system performance, which is not considered.

In this article first, inputs data of ANN are temperature and irradiance. They are given to GA then, optimal voltage (Vmpp) corresponding to the MPP is the output of ANN finally, the optimum values are utilized for training the. Photovoltaic module was connected to grid using a p-q controller of grid side to exchange active and reactive power and observe system efficiency in different weather conditions.

The paper is organized as follows: In part 2 detail of PV system is presented. Parts 3 and 4 discussed steps to implement the GA and neural networks, respectively. In part $5 \mathrm{p}$-q controller is described and in part 6 the results are presented based on current study.

\section{PHOTOVOLTAIC CELL MODEL}

Figure.1 shows equivalent circuit of one photovoltaic array [2], [3]. Features of PV system is described as following Equation (1)

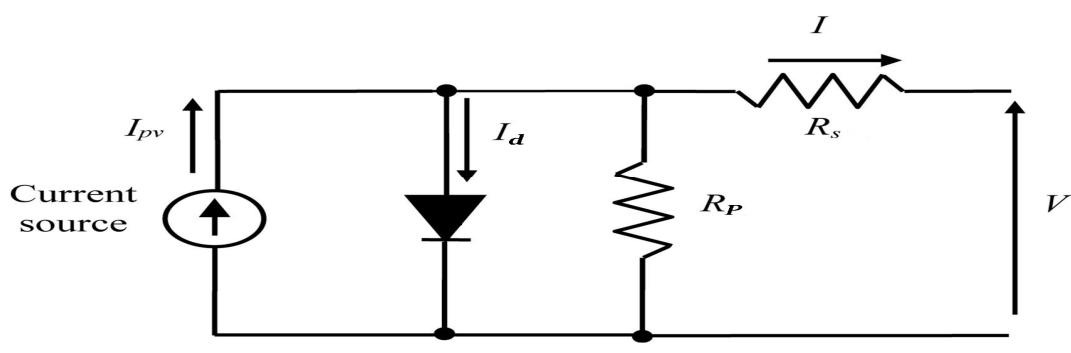

Figure. 1. Equivalent circuit of one photovoltaic array 


$$
I=I_{p v}-I_{0}\left[\exp \left(\frac{V+R_{S} I}{V_{t} n}\right)-1\right]-\frac{V+R_{s} I}{R_{P}}
$$

Where, $I$ is the output current, $V$ is the output voltage, $I_{p v}$ is the generated current under a given insolation, $I_{0}$ is the diode reverse saturation current, $n$ is the ideality factor for a $p-n$ junction, $R_{s}$ is the series loss resistance, and $\mathrm{R}_{\text {sh }}$ is the shunt loss resistance. $\mathrm{V}_{\text {th }}$ is known as the thermal voltage. Table 1 shows the Characteristic of red sun $90 \mathrm{w}$.

Table 1: Red sun 90w module

\begin{tabular}{|l|c|}
\hline $\mathrm{I}_{\mathrm{MP}}$ ( Current at maximum power) & $4.94 \mathrm{~A}$ \\
\hline $\mathrm{V}_{\mathrm{MP}}$ ( Voltage at maximum power) & $18.65 \mathrm{~V}$ \\
\hline $\mathrm{P}_{\mathrm{MAX}}$ (Maximum power) & $90 \mathrm{~W}$ \\
\hline $\mathrm{V}_{\mathrm{OC}}$ ( Open circuit voltage) & 22.32 \\
\hline $\mathrm{I}_{\mathrm{SC}}$ ( Short circuit current) & 5.24 \\
\hline $\mathrm{N}_{\mathrm{P}}$ (Total number of parallel cells) & 1 \\
\hline $\mathrm{N}_{\mathrm{S}}$ ( Total number of series cells) & 36 \\
\hline
\end{tabular}

\section{MPPT - ANN and GA}

\subsection{The Steps of Implementing Genetic Algorithm}

In order to pursue the optimum point for maximum power in any environmental condition, ANN and GA technic are used. Besides, GA is used for optimum values and then optimum values are used for training ANN [19, 21, 22]. The procedure employed for implementing genetic algorithm is as follows [21]: 1. determining the target function 2. determining the initial population size, 3 . appraising the population using the target function, and 4 . conducting convergence test stop if convergence is provided.

The target function of GA is applied for its optimization by the following: finding the optimum $\mathrm{X}=\left(\mathrm{X}_{1}, \mathrm{X}_{2}, \mathrm{X}_{3}, \ldots, \mathrm{X}_{\mathrm{n}}\right)$ to determine the $\mathrm{F}(\mathrm{X})$ in the maximum value, where the number of design variables are regarded as $1 . X$ is the design variable equal to $P V$ system current and also, $F(X)$ is the PV system output power that must be maximized [21]. To determine the target function, the power should be set based on the PV system current (IX). The genetic algorithm structures are presented in Table 2.

$$
\begin{aligned}
& \mathrm{F}_{(\mathrm{X})}=\mathrm{V}_{\mathrm{X}} * \mathrm{I}_{\mathrm{X}} \\
& 0<\mathrm{I}_{\mathrm{X}}<\mathrm{I}_{\mathrm{SC}}
\end{aligned}
$$

The current constraint should be considered too. With maximizing this function, the optimum values for Vmpp and MPP will result in any particular temperature and irradiance intensity. 
International Journal of Soft Computing, Mathematics and Control (IJSCMC), Vol. 3, No. 4, November 2014

Table 2: Genetic algorithm structures

\begin{tabular}{|c|c|}
\hline Number of Design Variable & 1 \\
\hline Population size & 25 \\
\hline Crossover constant & $75 \%$ \\
\hline Mutation rate & $14 \%$ \\
\hline Maximum Generations & 16 \\
\hline
\end{tabular}

\section{COMBINATION of ANN- GA}

ANN are most suitable for the prediction of nonlinear systems. Non-linear systems can be approximated by multi-layer neural networks and these multi-layer networks have better result in comparison with the other algorithm [16, 18]. In this paper, feed forward neural network for MPPT process control is used. The main part of this method is that, the required data for training process should be achieved for each PV system and each particular position [11]. Based on the PV characteristic which depend on PV model and climate change, neural network should be trained periodically. Neural network inputs can be selected as PV array parameters like $V_{\mathrm{oc}}, \mathrm{I}_{\mathrm{sc}}$ and climate data, temperature or both of them. The output is usually one reference signal like duty cycle or DC link voltage or Vmpp.

Three layers can be considered for the proposed ANN. The input variables are temperature and solar irradiance and Vmpp corresponding to MPP is output variable of the neural network as shown in Figure 2. Also, a simple block diagram of the PV system with the proposed MPPT is shown in the Figure 3.

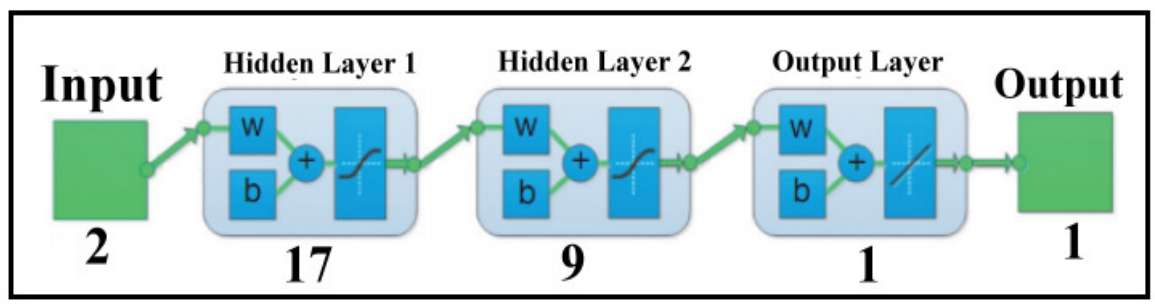

Figure. 2. Feed forward neural network for MPPT 


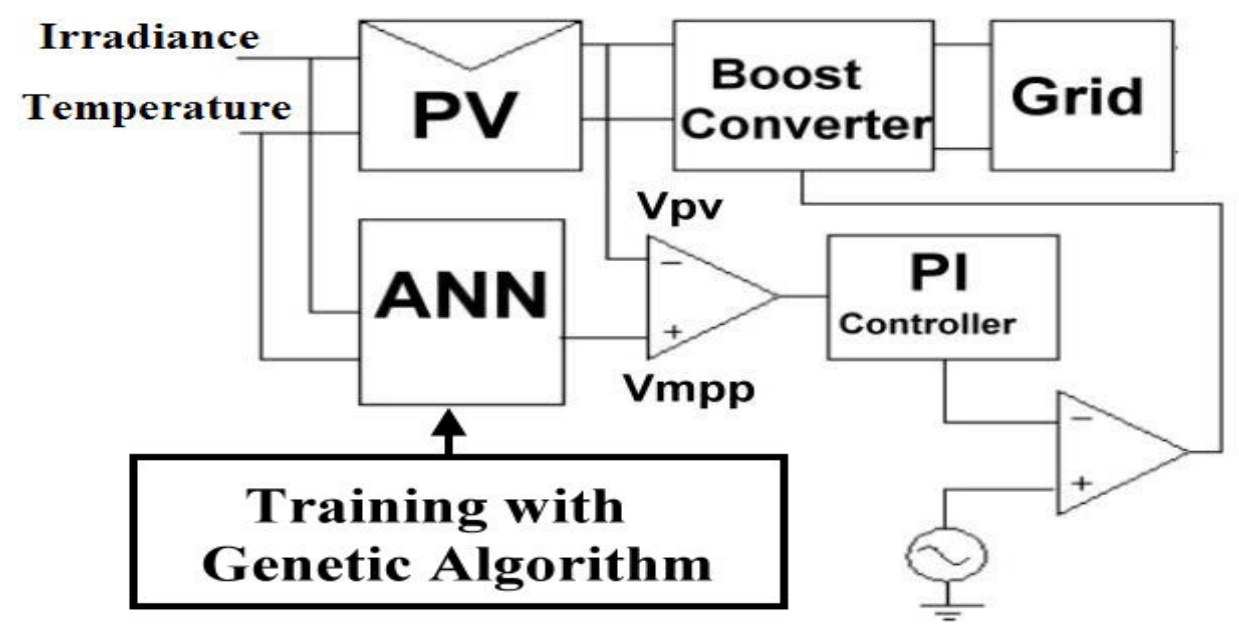

Figure. 3. Structure of suggested MPPT

The output of PV system has varied during time and environmental conditions. Thus, periodic training of the ANN is needed. Training of the ANN is a set of 500 data as shown in figure 4. ( irradiance between 0.05 to 1 watt per square meter $\left(\mathrm{W} / \mathrm{m}^{2}\right)$ and temperatures between $-5{ }^{\circ} \mathrm{C}$ to 55 ${ }^{\circ} \mathrm{C}$ ) and also, a set of $500 \mathrm{Vmpp}$ corresponding to MPP is obtained by GA as shown in Figure 5.

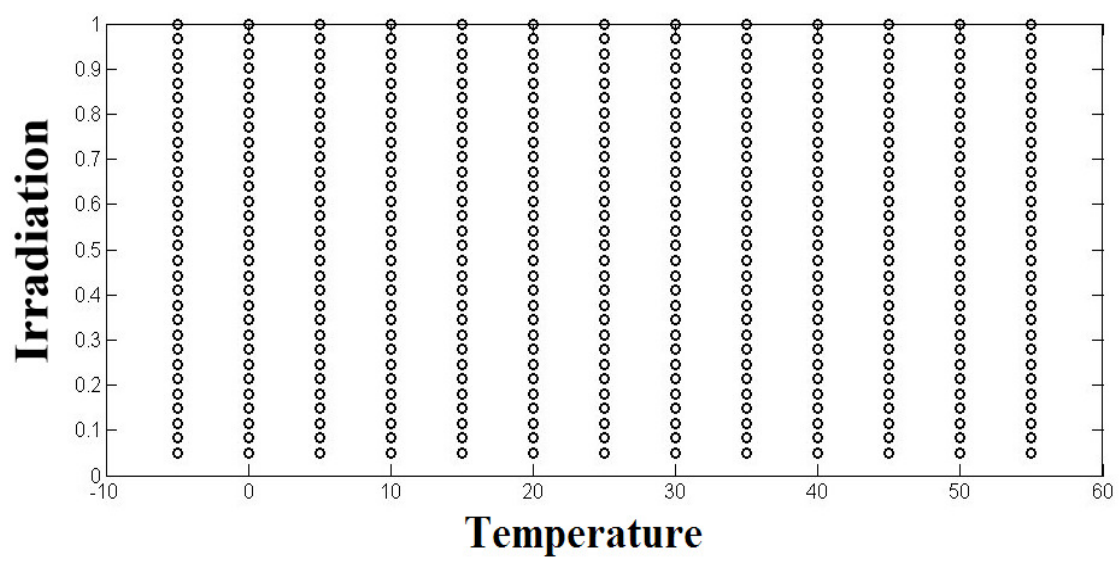

Figure. 4. Inputs data of irradiation and temperature 
International Journal of Soft Computing, Mathematics and Control (IJSCMC), Vol. 3, No. 4, November 2014

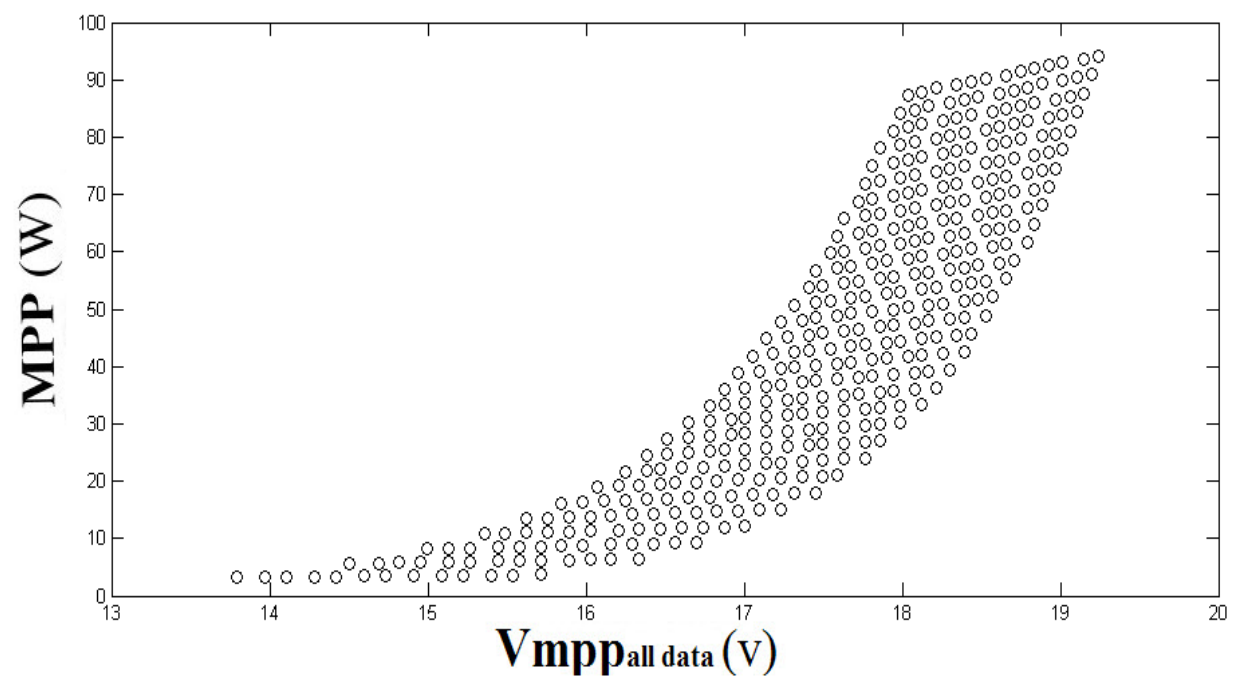

Figure. 5. The outputs of Vmpp - $\mathrm{M}_{\mathrm{pp}}$

To perform of the ANN for MPPT, first, the number of layers, number of neurons in each layer, transmission function in each layer and kind of training network should be defined. The proposed ANN in this paper has three layers which first and second layers have respectively 17 and 9 neurons and third layer has 1 neuron. The first and second layers of the transfer functions are Tansig and third layer is Purelin. The training function is Trainlm. The satisfactory sum of squares for the ANN is determined to be $10^{-9}$. Which training this neural network in 950 iterations, will converge to a desired target. After training, the output of training network should be close to optimum output from GA. The neural network training with the target data as shown in figure 6. A set of 80 data is applied for the ANN test. The neural network test with the target data, showing a trifling training error percentage about $0.3 \%$ as shown in figure7.

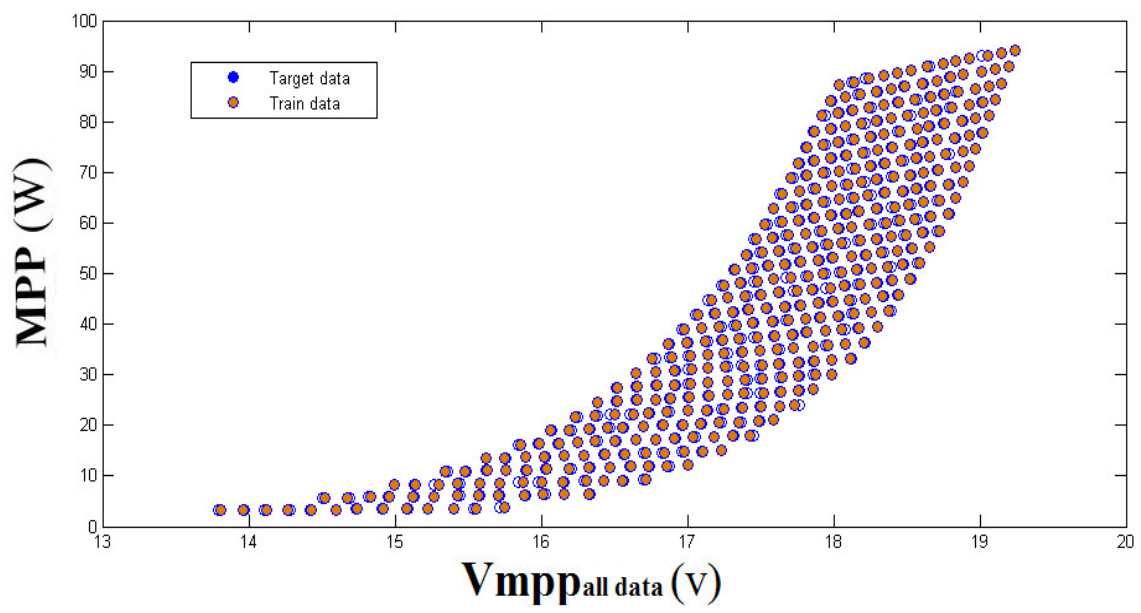

6(a) 
International Journal of Soft Computing, Mathematics and Control (IJSCMC), Vol. 3, No. 4, November 2014

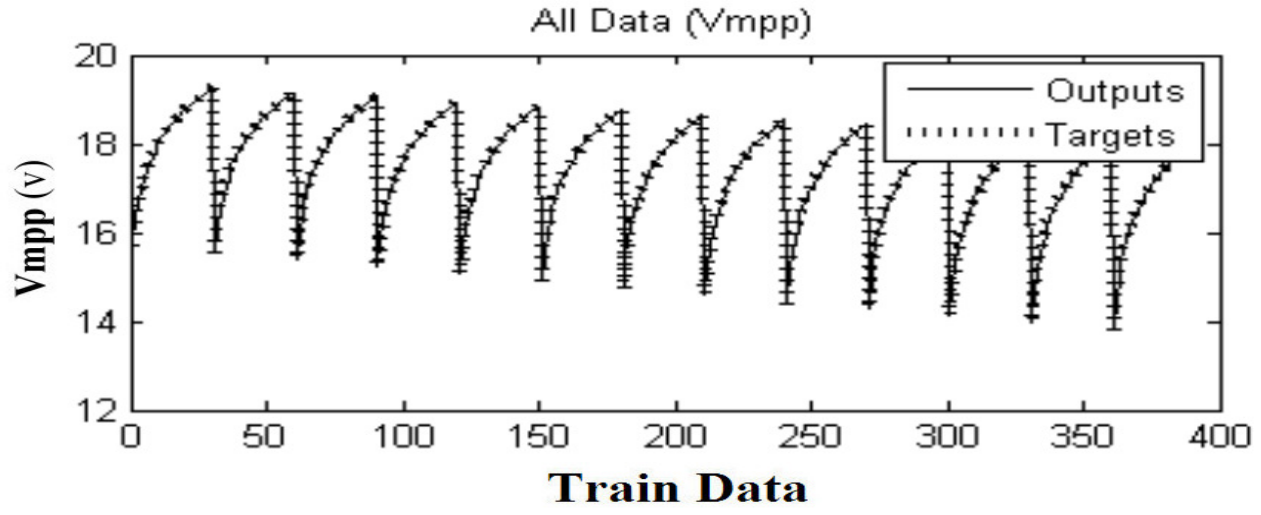

6(b)

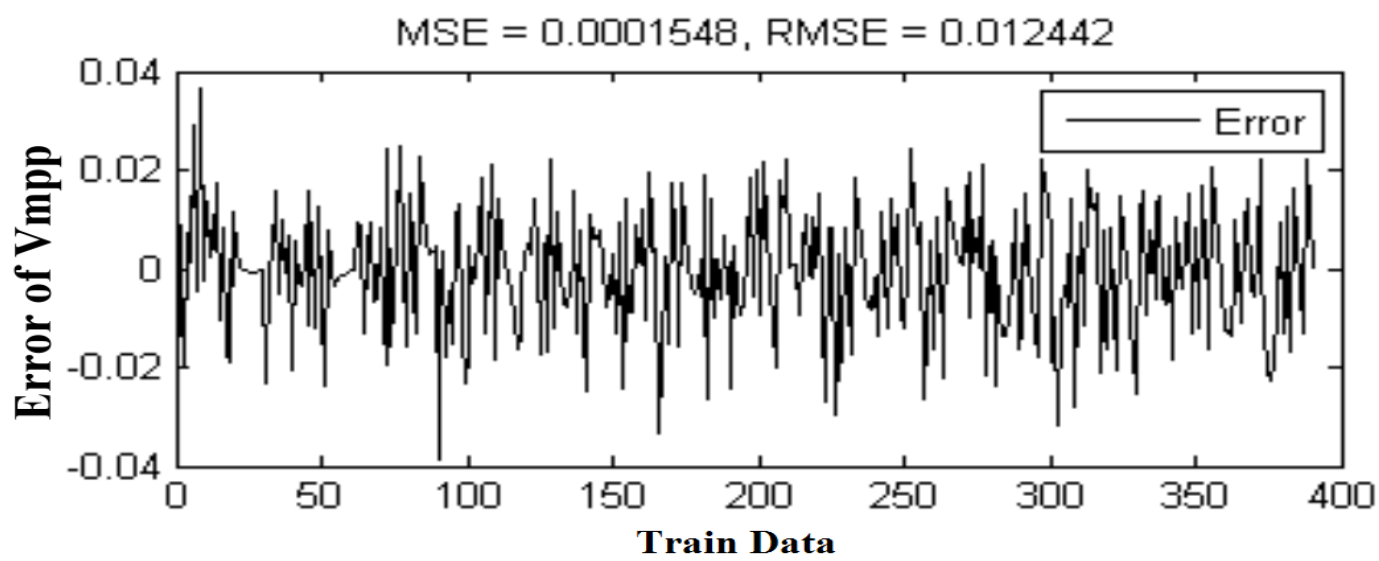

6(c)

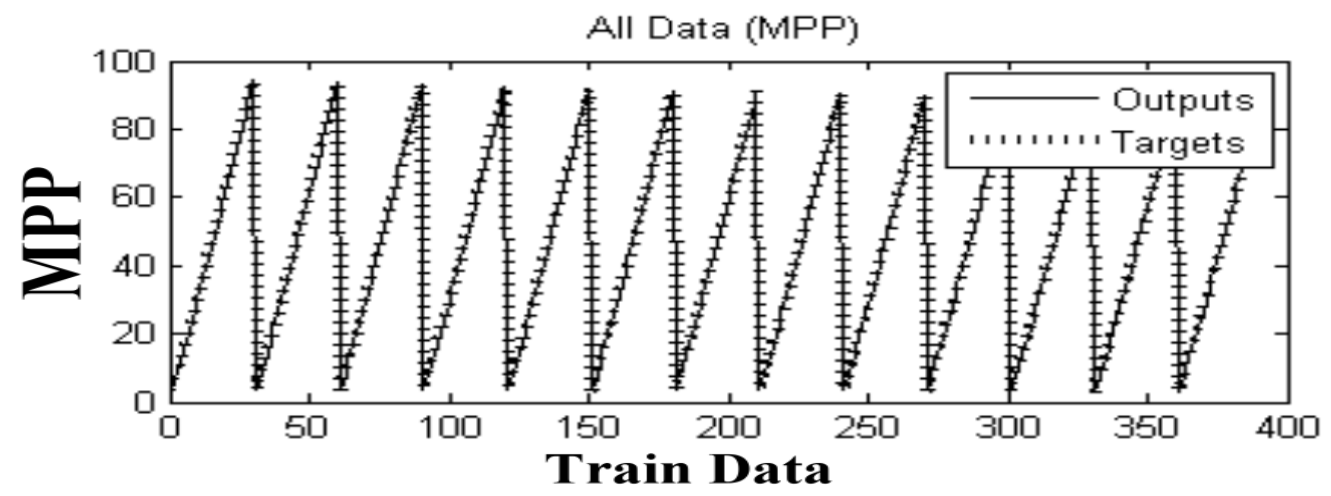

6(d) 
International Journal of Soft Computing, Mathematics and Control (IJSCMC), Vol. 3, No. 4, November 2014

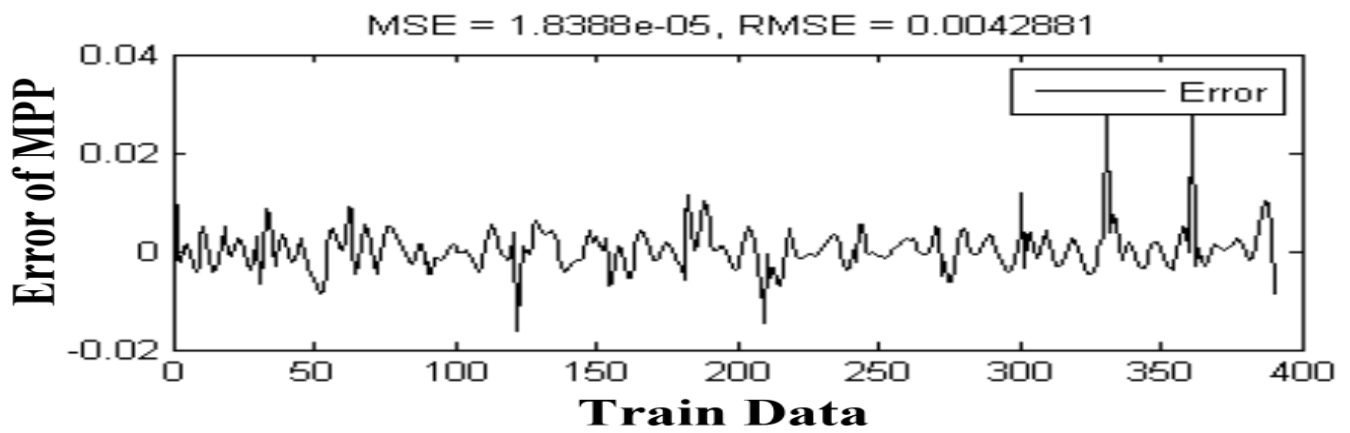

6(e)

Figure. 6. shown the output of the neural network by fallowing: (a) The neural network training with the target data; (b) The neural network of Vmpp with the amount of data; (c) total error percentage of the Vmpp; (d) The neural network of MPP with the amount of the target data;(e) total error percentage of the MPP data.

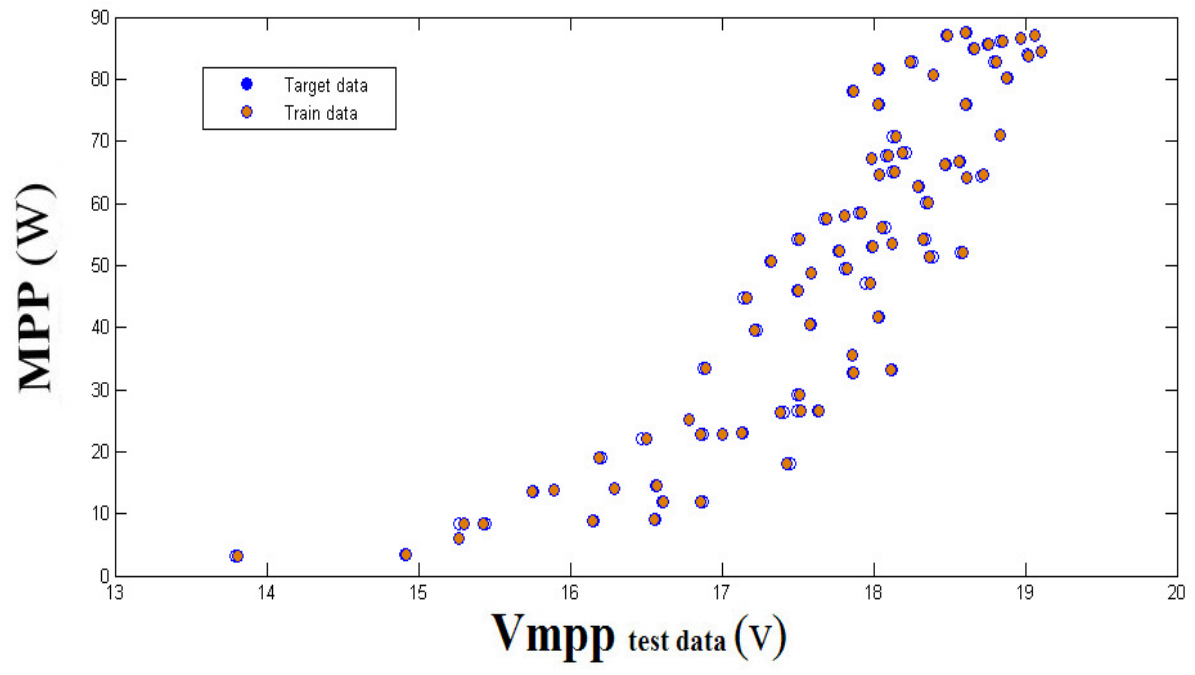

$7(a)$

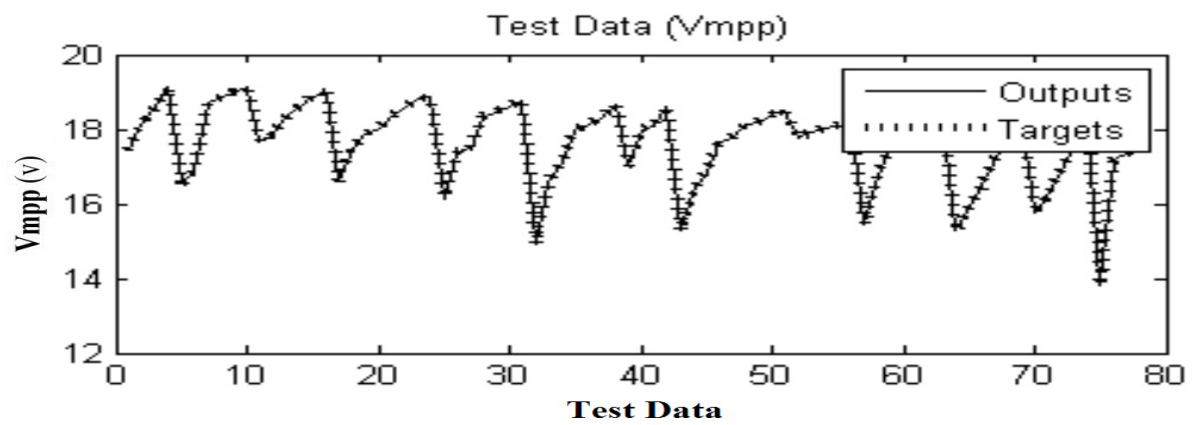

7(b) 
International Journal of Soft Computing, Mathematics and Control (IJSCMC), Vol. 3, No. 4, November 2014

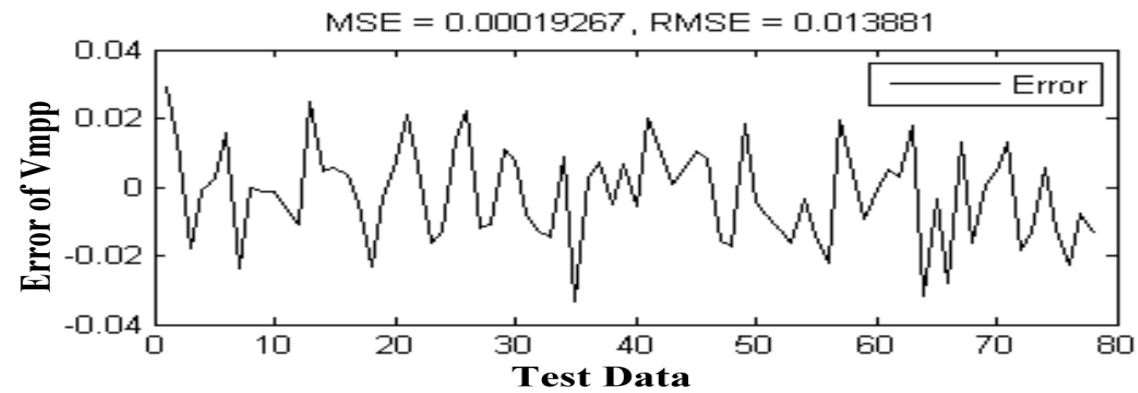

$7(\mathrm{c})$

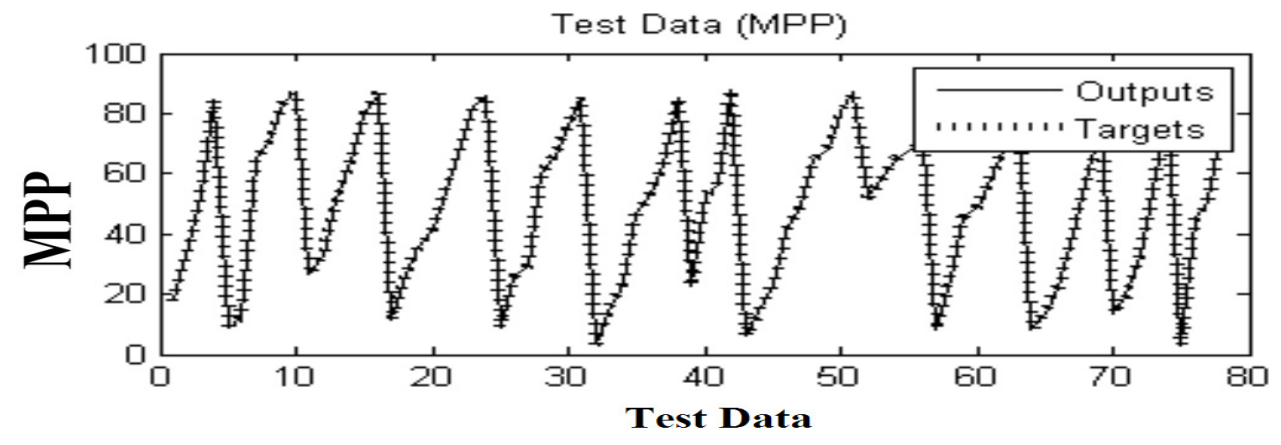

$7(d)$

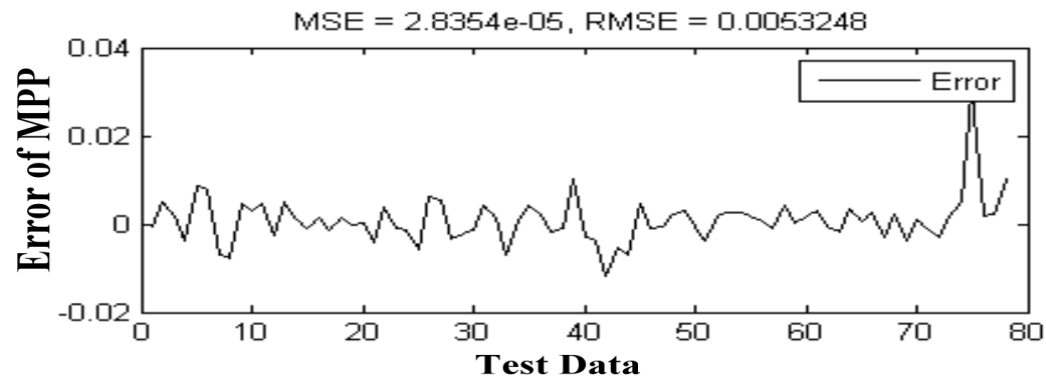

$7(\mathrm{e})$

Figure. 7. shown the output of the neural network test by following: (a) The neural network test with the target data; (b) The neural network test of Vmpp with the test target data; (c) Percentage error of test data Vmpp; (d) The neural network test of MPP with the amount of target data; (e) Percentage error of MPP test data.

\section{CONTROL STRATEGY (P-Q)}

A three phase DC-AC voltage source inverter (VSI) is used for grid connection via pulse width modulation (PWM) technic. By applying inverter via PWM technic produces high frequency harmonics which lead to filter and eliminate the harmonics. The VSI can play role as an ideal sinusoidal voltage source. 
Synchronous reference is calculate quantities of d-axis, q-axis and zero sequence in two axis rotational reference vector for three phase sinusoidal signal illustrated in Figure 8. The equations are given by (4), (5).

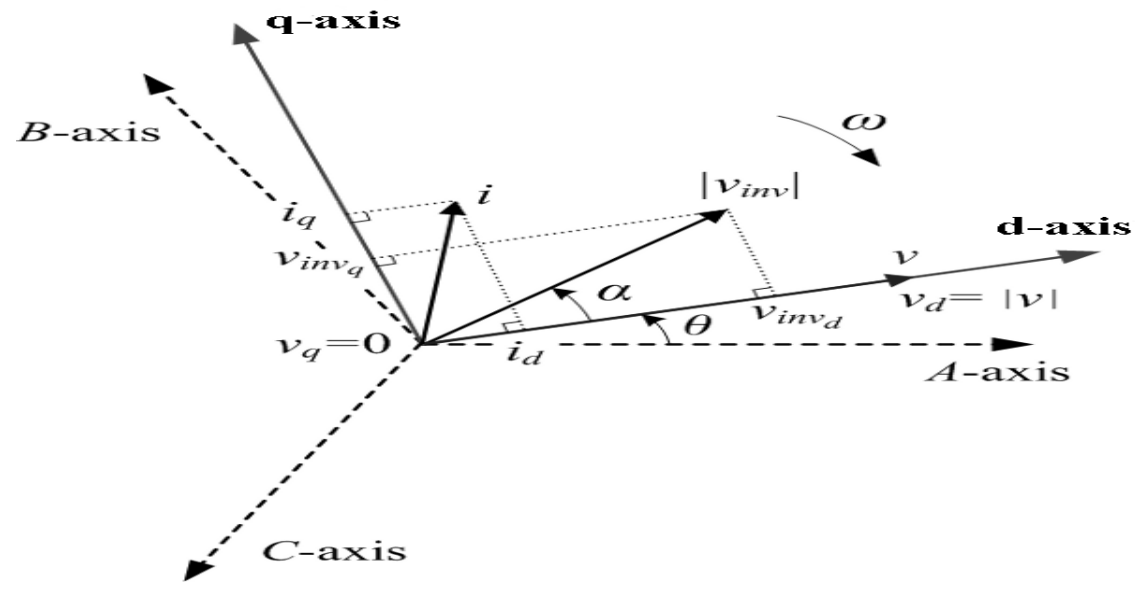

Figure 8. The synchronous reference machine

$$
\begin{aligned}
& {\left[\begin{array}{l}
\mathrm{V}_{\mathrm{d}} \\
\mathrm{V}_{\mathrm{q}} \\
\mathrm{V}_{0}
\end{array}\right]=\mathrm{C}\left[\begin{array}{l}
\mathrm{V}_{\mathrm{a}} \\
\mathrm{V}_{\mathrm{b}} \\
\mathrm{V}_{\mathrm{c}}
\end{array}\right],\left[\begin{array}{l}
\mathrm{i}_{\mathrm{d}} \\
\mathrm{i}_{\mathrm{q}} \\
\mathrm{i}_{0}
\end{array}\right]=\mathrm{C}\left[\begin{array}{l}
\mathrm{i}_{\mathrm{a}} \\
\mathrm{i}_{\mathrm{b}} \\
\mathrm{i}_{\mathrm{c}}
\end{array}\right]} \\
& \mathrm{C}_{\mathrm{dq} 0}=\frac{2}{3}\left[\begin{array}{ccc}
\cos \theta & \cos (\theta-2 \pi / 3) & \cos (\theta+2 \pi / 3) \\
-\sin \theta & -\sin (\theta-2 \pi / 3) & -\sin (\theta+2 \pi / 3) \\
\frac{1}{2} & \frac{1}{2} & \frac{1}{2}
\end{array}\right]
\end{aligned}
$$

Inverter control model is illustrated in Figure.9 The goal of controlling the grid side, is keeping the dc link voltage in a constant value regardless of production power magnitude. Internal control-loop which control the grid current and external control loop which control the voltage [23]. Also, internal control-loop which is responsible for power quality such as low THD and improvement of power quality and external control-loop is responsible for balancing the power. For reactive power control, reference voltage will be set same as dc link voltage. In gridconnected mode, photovoltaic module must supply local needs to decrease power from the main grid. One the main aspects of p-q control loop is grid connection and stand-alone function. The advantages of this operation mode are higher power reliability and higher power quality. 


$$
\begin{aligned}
& \mathrm{P}=\frac{3}{2}\left(V_{g d} I_{d}+V_{g q} I_{q}\right) \\
& \mathrm{Q}=\frac{3}{2}\left(V_{g q} I_{d}-V_{g d} I_{q}\right)
\end{aligned}
$$

If synchronous frame is synchronized with grid voltage, voltage vector is $\mathrm{V}=\mathrm{V}_{\mathrm{gd}}+\mathrm{j} 0$ which active and reactive power may be as following:

$$
\begin{aligned}
& \mathrm{P}=\frac{3}{2} V_{g d} I_{d} \\
& \mathrm{Q}=\frac{3}{2} V_{g d} I_{q}
\end{aligned}
$$

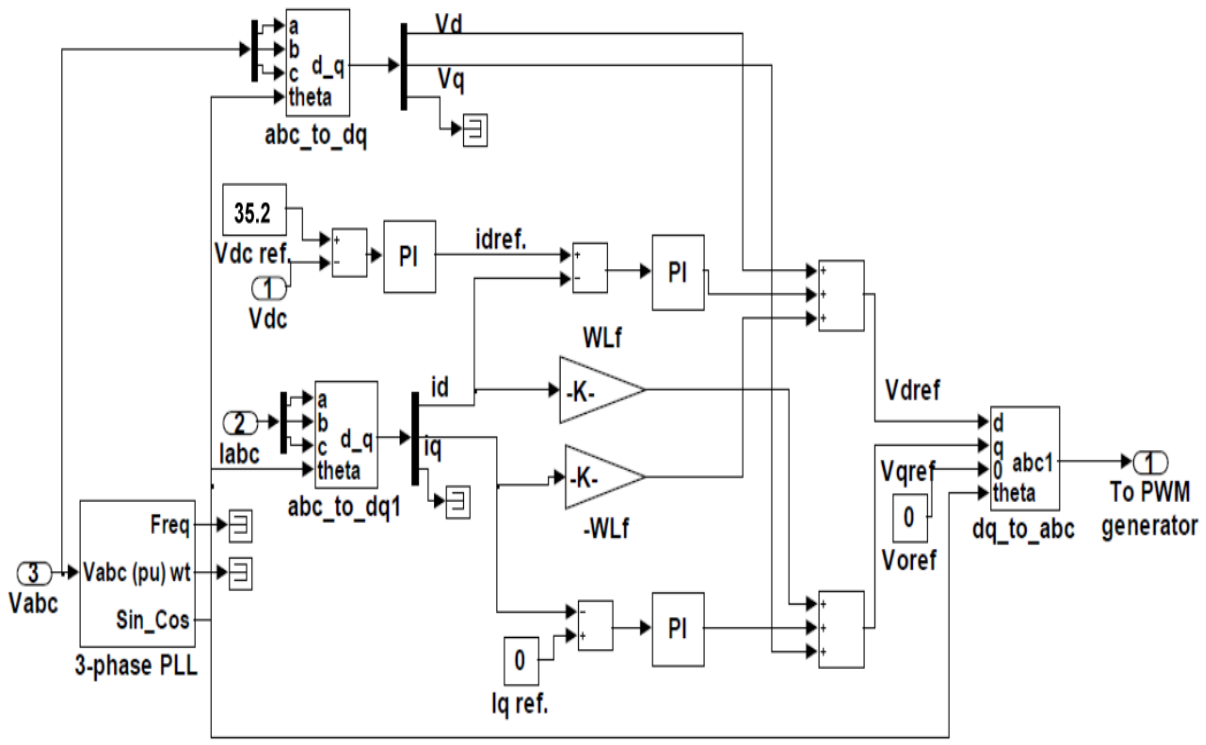

Figure. 9. The inverter control model

\section{SIMULATION RESULTS}

In this section, simulation results under different terms of operation use with Matlab /Simulink is presented. System block diagram is shown in Figure. 10. Detailed model descriptions are given in Appendix A. 


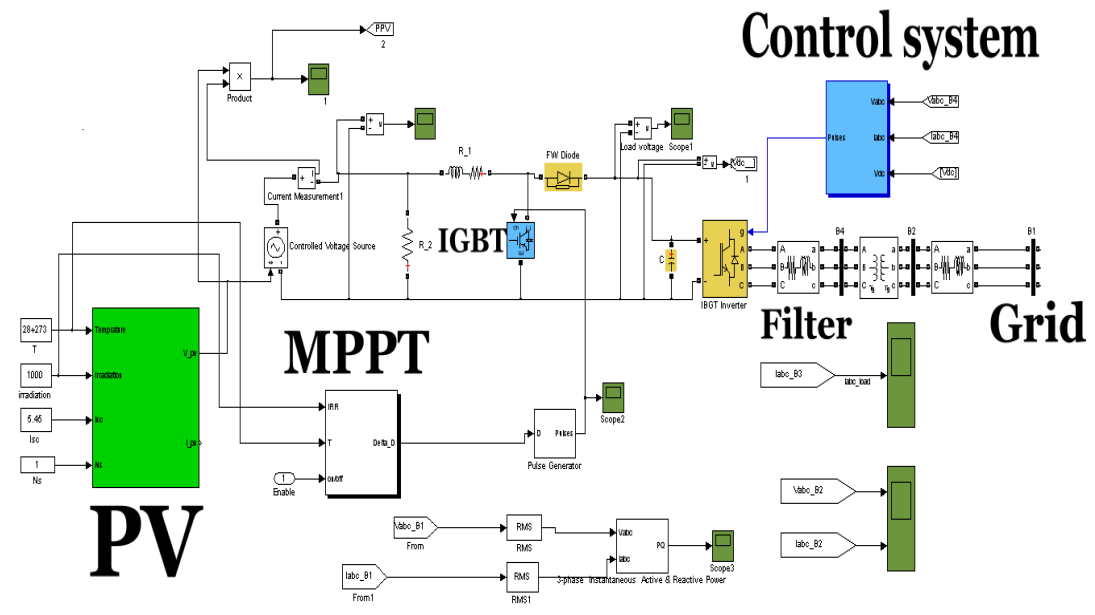

Figure. 10. Case study system

\subsection{Different conditions of Irradiance and Temperature}

The MPPT methods under different conditions of irradiance and temperature in PV system are investigated in this case. The system is connected to the main grid that includes $90 \mathrm{~W}$ photovoltaic system and the amount of load is $90 \mathrm{~W}$. There is no power exchange between photovoltaic system and grid in normal condition.

The simulation results are described for variation insolation levels at constant temperature of $25^{\circ} \mathrm{C}$ as shown in Figure 11(a). The output voltage and the current of PV are depicted in Figures 11 (b) and 11 (c), respectively. When irradiance is increased at $t=4$ and $t=8$, it lead to increase in the output current of PV as shown in Figure 11(c). The evaluation of the proposed controller is compared and analyzed with the conventional technique of P\&O. The proposed MPPT algorithm can track accurately the MPP when the irradiance changes continuously; also, it produces extra power rather than aforementioned method as indicated in Figure 11(d). Therefore, the injected power from main grid to photovoltaic system is decreased as demonstrated in Figure 11(e).

Performance of the ANN-GA method under different temperature levels at constant insolation of $1000 \mathrm{~W} / \mathrm{m}^{2}$ as shown in Figure 12(a). The grid voltage is indicated in Figure 12(b). Figure 12(c) shows the variation of the output current of PV. The ANN-GA method shows smother power, less oscillating and better stable operating point than P\&O. It has more accuracy for operating at MPP and also, it generates exceeding power rather than mentioned technique as depicted in Figure 12(d). Consequently, the grid power injection to photovoltaic system is declined as illustrated in Figure 12(e). 
International Journal of Soft Computing, Mathematics and Control (IJSCMC), Vol. 3, No. 4, November 2014

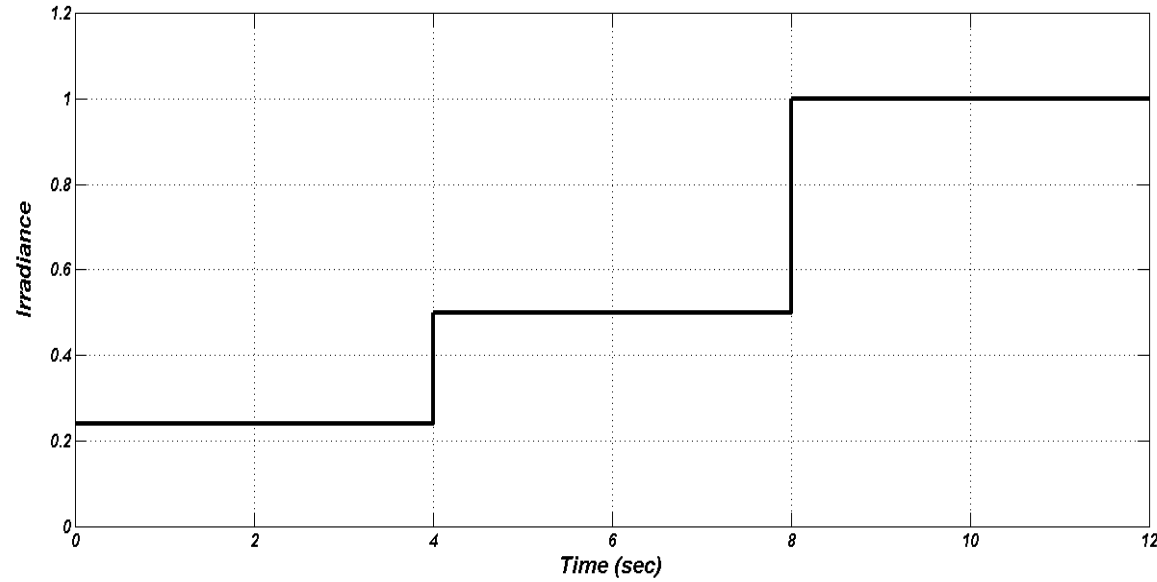

$11(\mathrm{a})$

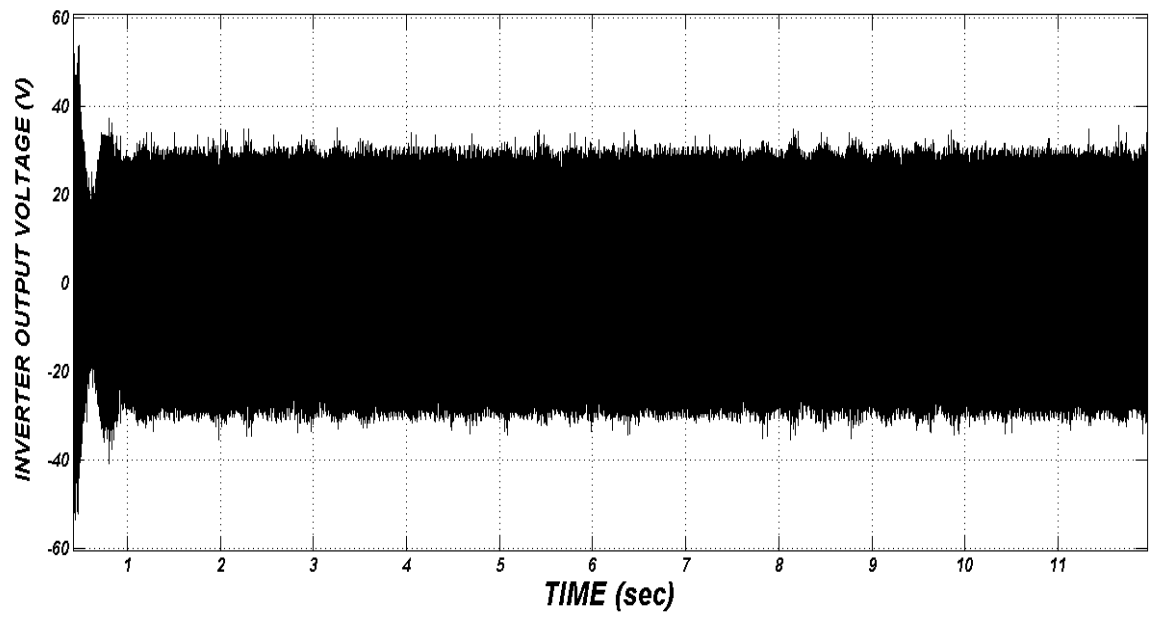

11(b)

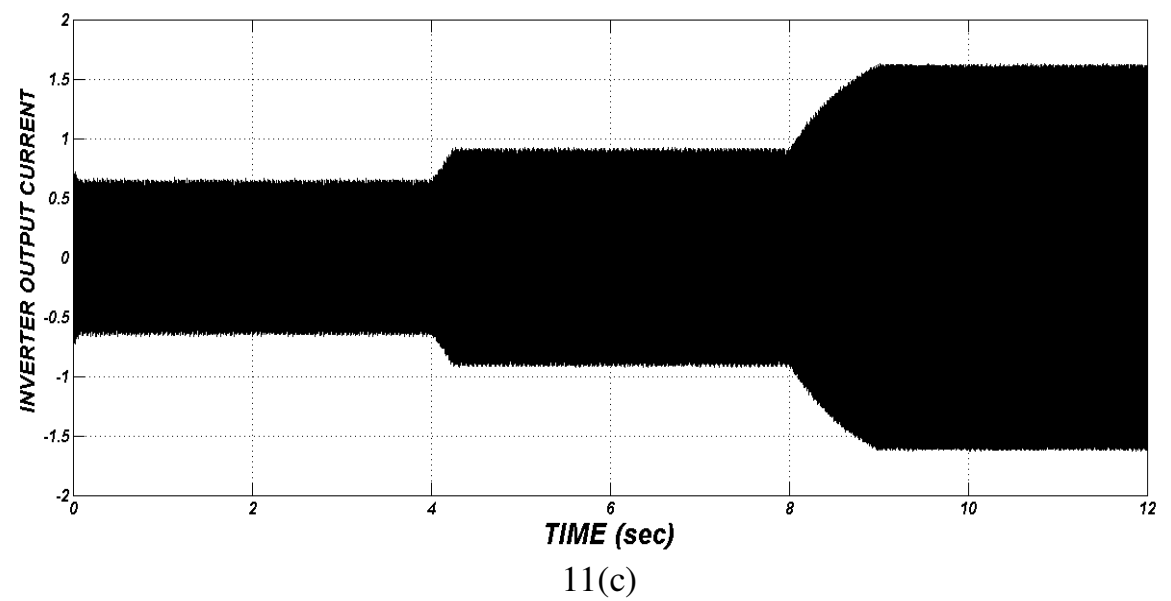


International Journal of Soft Computing, Mathematics and Control (IJSCMC), Vol. 3, No. 4, November 2014

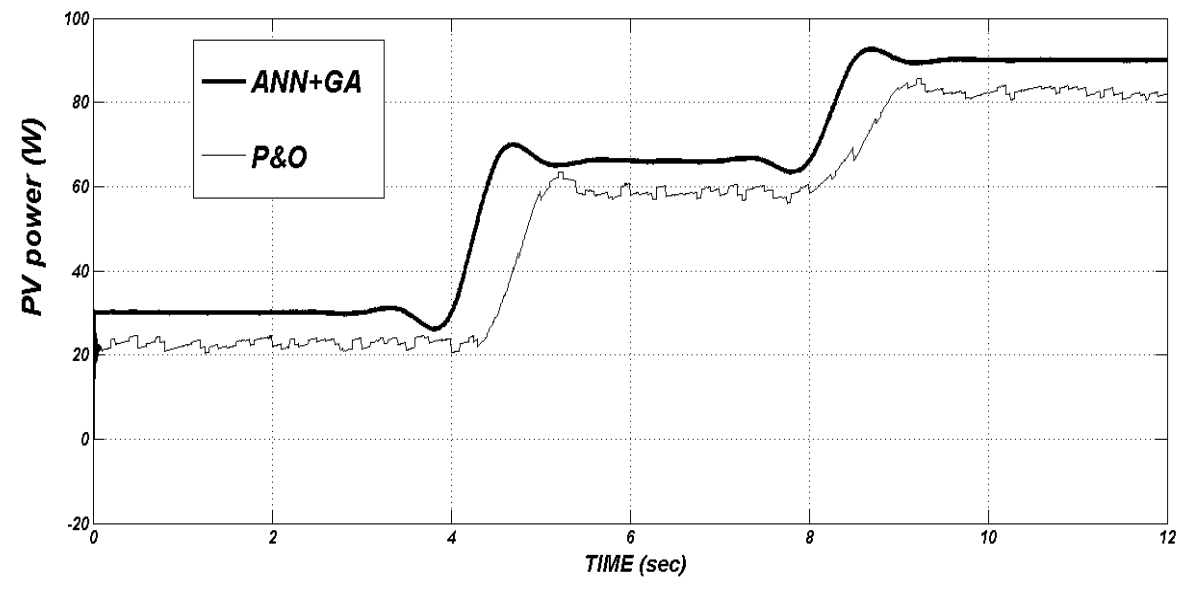

11(d)

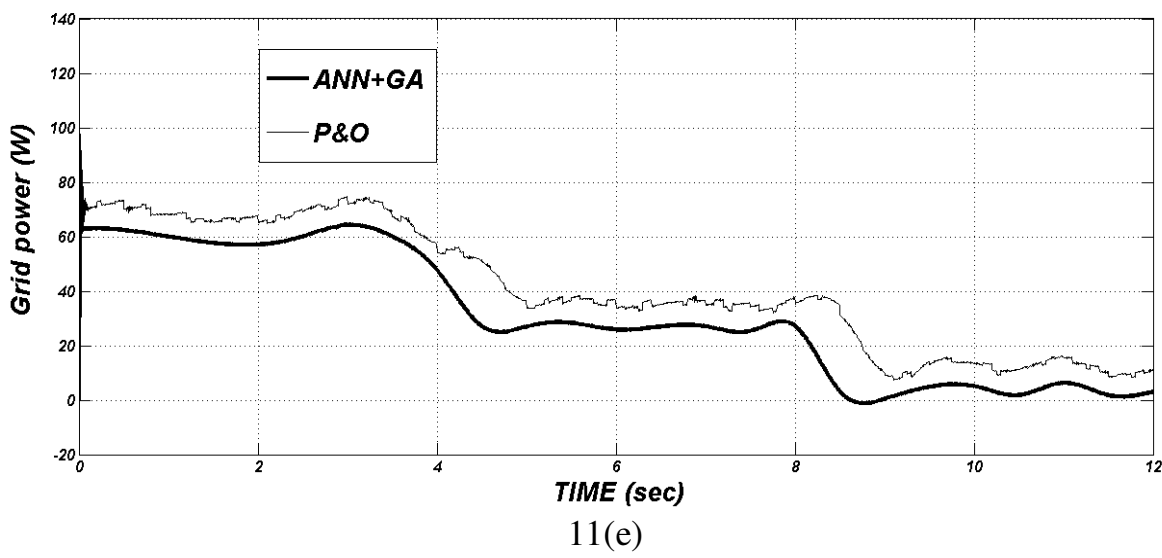

Figure 11. Simulated results for PV (Variation of Irradiance) in case 1: (a) Irradiance; (b) Inverter output voltage; (c) Inverter output current; (d) PV power; (e) Grid power.

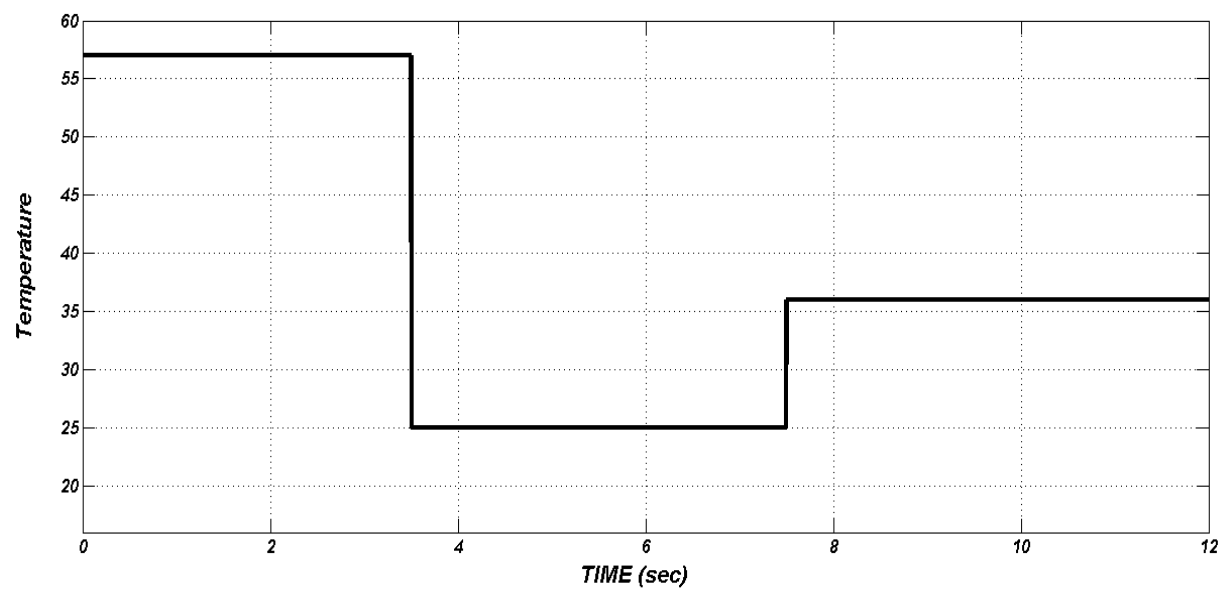

12(a) 
International Journal of Soft Computing, Mathematics and Control (IJSCMC), Vol. 3, No. 4, November 2014

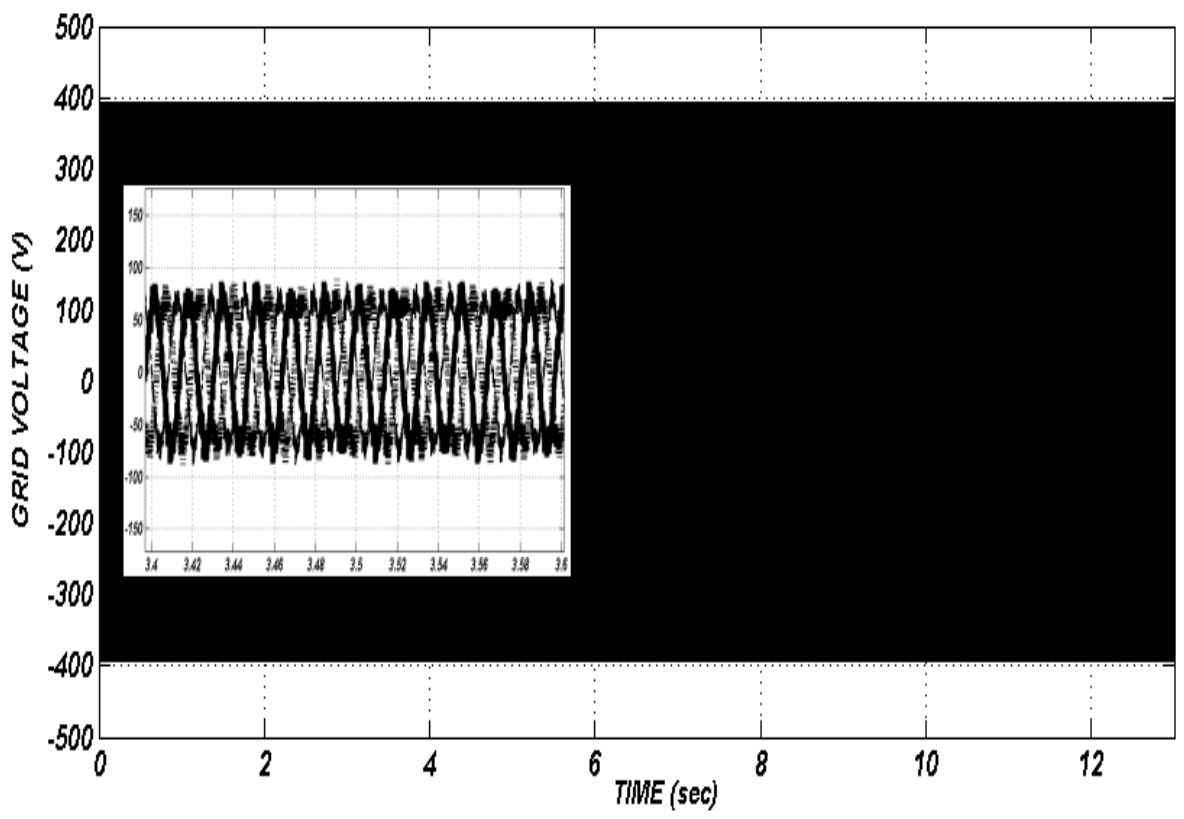

12(b)

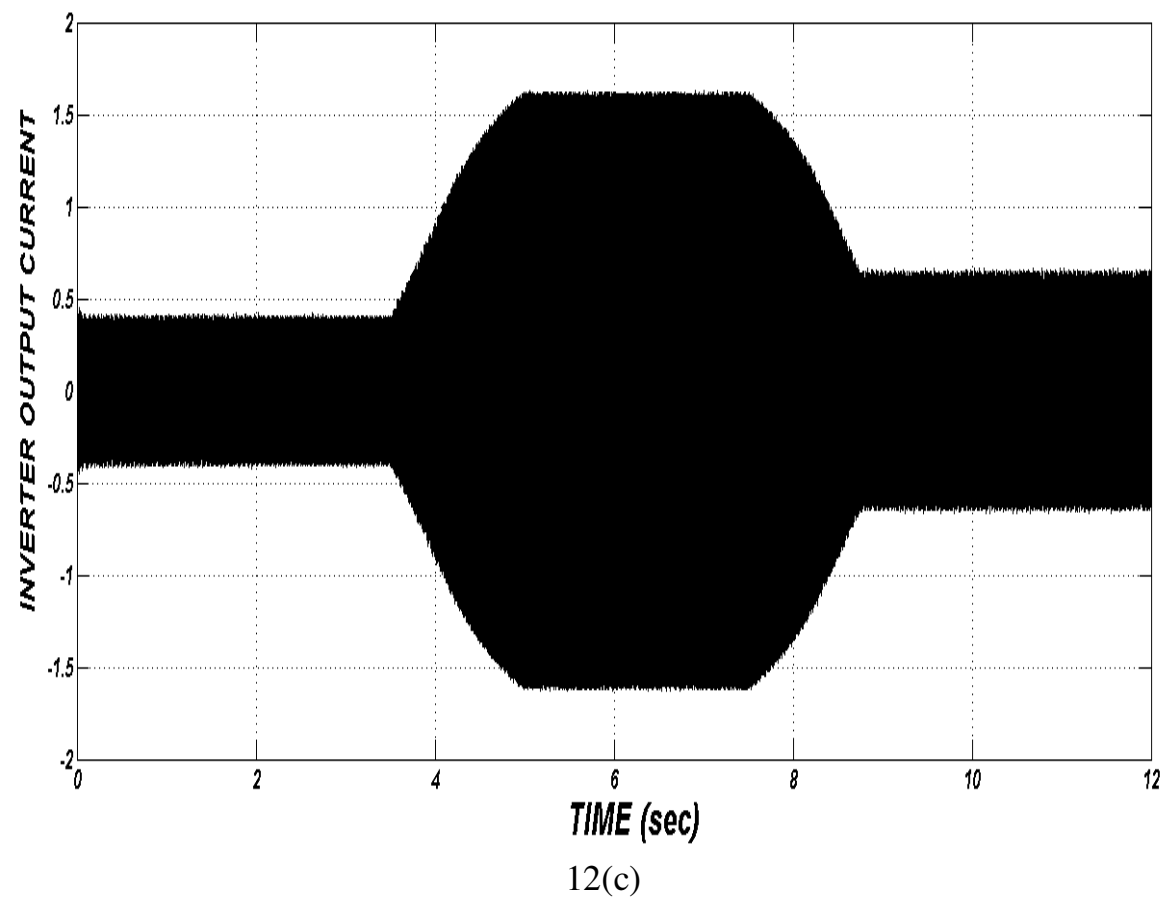


International Journal of Soft Computing, Mathematics and Control (IJSCMC), Vol. 3, No. 4, November 2014
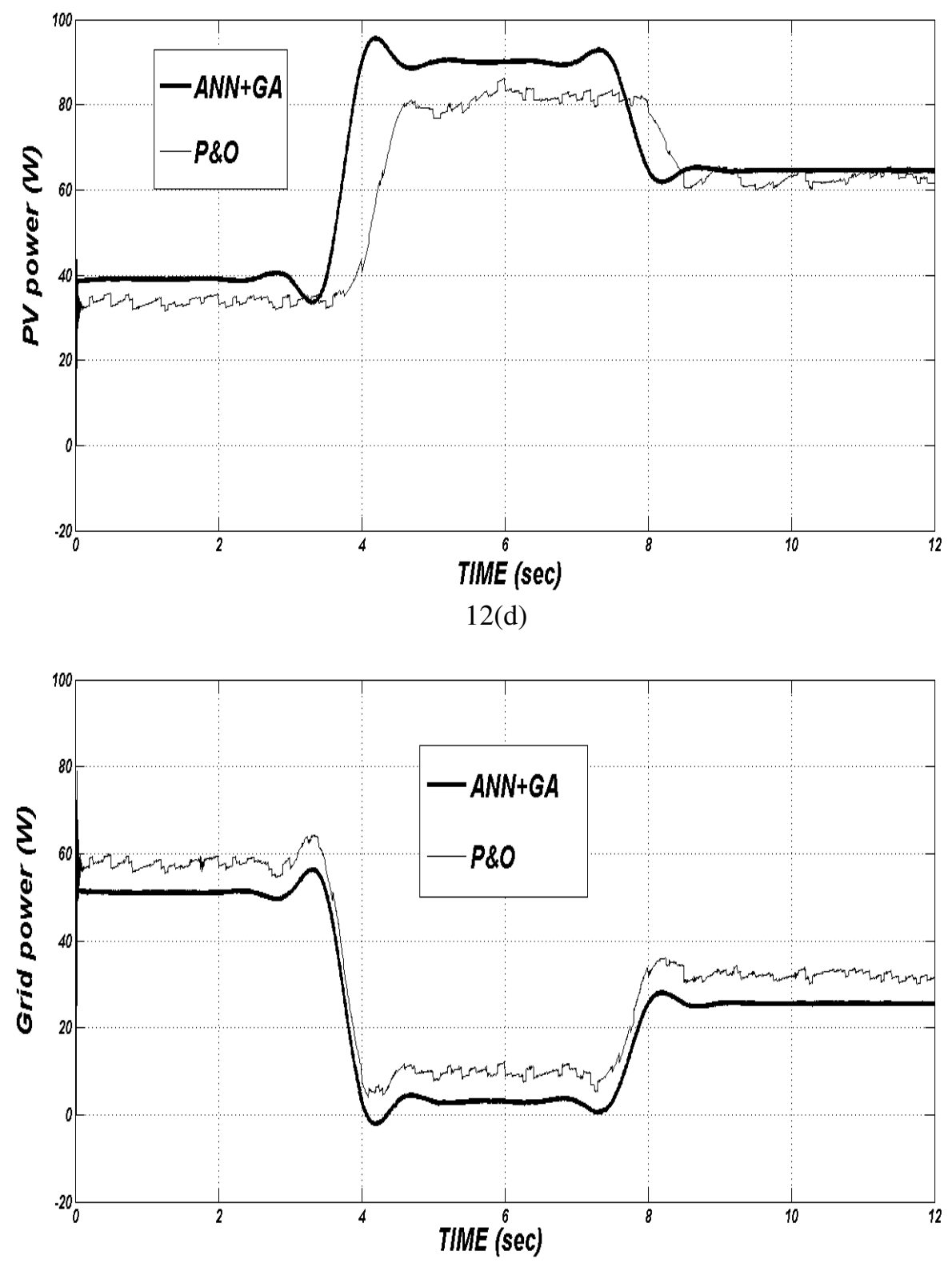

$12(\mathrm{e})$

Figure 12. Simulated results for PV (Variation of Temperature) in case 1: (a) Temperature; (b) Grid voltage; (c) Inverter output current; (d) PV power; (e) Grid power.

\section{CONCLUSIONS}

The presented study is a kind of modelling and analysis of the PV system under fault circumstances by using ANN-GA. To extract the maximum power from the PV system ANN-GA technique is used. The GA based offline trained ANN is used to provide the reference voltage corresponding to the maximum power for any environmental changes. The simulation results 
International Journal of Soft Computing, Mathematics and Control (IJSCMC), Vol. 3, No. 4, November 2014

show that using ANN-GA controller can dramatically reduce the disadvantages of previous approaches and also, it can decrease oscillations of power output around the maximum power point and can increase convergence speed to achieve the maximum power point in comparison with $\mathrm{P} \& \mathrm{O}$ method. In order to control the grid current and voltage, a grid-side controller, are applied. Inverter adjusts the dc link voltage and Active power is fed by $\mathrm{d}$ axis and reactive power is fed by q axis (using PQ control mode). Finally, by applying the appropriate controller, the photovoltaic system in grid-connected mode, can meet the need of load assuredly.

\section{Appendix A: Description of the Detailed Model}

Photovoltaic parameters: output power $=90 \mathrm{~W}$, Carrier frequency in $\mathrm{V}_{\mathrm{MPPT}}$ PWM generator: 4000 $\mathrm{Hz}$ and in grid-sid controller: $6000 \mathrm{~Hz}$, boost converter parameters: $\mathrm{L}=0.07 \mathrm{H}, \mathrm{C}=0.087$, PI coefficients in grid-side controller: $\mathrm{K}_{\mathrm{pVdc}}=0.2, \mathrm{k}_{\mathrm{iVdc}}=5, \mathrm{~K}_{\mathrm{pId}}=9, \mathrm{~K}_{\mathrm{ild}}=500, \mathrm{~K}_{\mathrm{pIq}}=9, \mathrm{~K}_{\mathrm{ilq}}=500$ , Vgrid= 220 Now, two cases are investigated

\section{REFERENCES}

[1] A.Rezvani, M.Gandomkar, M.Izadbakhsh and A.Ahmadi,'Environmental/economic scheduling of a micro-grid with renewable energy resources', Journal of Cleaner Production,Vol.87, pp. 216-226, 2015.

[2] M.Izadbakhsh, M.Gandomkar, A.Rezvani and A.Ahmadi,"'Short-term resource scheduling of a renewable energy based micro grid”, Renewable Energy,Vol.75, pp.598-606, 2015.

[3] V. Salas, E. Olias, A. Barrado, A. Lazaro, Review of the maximum power point tracking algorithms for stand-alone photovoltaic systems, Solar Energy Materials and Solar Cells, 90(11), pp.1555-1578, 2006.

[4] N. Femia, et al, Optimization of perturb and observer maximum power point tracking method, IEEE Transactions on Power Electronics, 20 (4), pp.963-973, 2005.

[5] C.C. Chu, C.L. Chen, Robust maximum power point tracking method for photovoltaic cells: a sliding mode control approach, Solar Energy, 83(8), pp. 1370-1378, 2009.

[6] F. Liu, S. Duan, B. Liu, and Y. Kang, A variable step size INC MPPT method for PV systems, IEEE Trans. Industrial Electronics, 55 (7), pp.622-2628, 2008.

[7] M.A.S. Masoum , M. Sarvi ,An Optimal Fuzzy MPP Tracker Enhancing Battery Charging Performance of Photovoltaic Systems, International Journal of Power and Energy Systems,2003

[8] F. Bouchafaa, I. Hamzaoui, A. Hadjammar, Fuzzy Logic Control for the tracking of maximum power point of a PV system, Energy Procedia,6(1), pp.152-159, 2011.

[9] M. Veerachary, T. Senjyu, K. Uezato, Neural-network-based maximum-power-point tracking of coupled inductor interleaved-boost-converter-supplied PV system using fuzzy controller, IEEE Transactions on Industrial Electronics,50(4), pp.749-758,2003.

[10] A. K. Rai, N.D. Kaushika, B. Singh, N. Agarwal, Simulation model of ANN based maximum power point tracking controller for solar PV system, Solar Energy Materials and Solar Cells, 95(2), pp.773$778,2011$.

[11] A.A. Kulaksiz, ANN-based control of a PV system with maximum power point tracker and SVM inverter, Ph.D.Dissertation, Sel, cuk University Graduate School of Natural and Applied Sciences, Department of Electrical and Electronics Engineering, Konya, Turkey, 2007.

[12] L. Fangrui, et al., A Variable Step Size INC MPPT Method for PV Systems, IEEE Trans. on Industrial Electronics, 55(7), pp.2622-2628, 2008.

[13] T. Esram, P. L. Chapman, Comparison of photovoltaic array maximum power point tracking techniques, IEEE Transactions on Energy Conversion, 22(2), pp.439-449, 2007.

[14] M.G. Simoes, N.N. Franceschetti, Fuzzy Optimisation Based Control Of A Solar Array System, IEE Proceedings on Electric Power Applications, Vol. 146(5), pp.552 -558, 1999.

[15] D.P. Huh, M.E. Ropp, Comparative Study of Maximum PowerPoint tacking Algorithm Using an Experimental, Programmable, Maximum Power Point Tracking Test Bed, Proceedings of 28th IEEE Photovoltaic Specialists Conference, Alaska, pp.1699-1702, 2000. 
International Journal of Soft Computing, Mathematics and Control (IJSCMC), Vol. 3, No. 4, November 2014

[16] T. Hiyama, S. Kouzuma, T. Imakubo, T.H. Ortmeyer, Evaluation of Neural Network Based Real Time Maximum Power Tracking Controller Far PV System, IEEE Transaction On Energy Conversion, 10(3), pp.543-548, 1995.

[17] T. Hiyama, K. Kitabayashi, Neural Network Based Estimation of Maximum Power Generation from PV Module Using Environment Information, IEEE Transaction on Energy, Conversion, 12(3), 1997, pp.241-247.

[18] E. Karatepe, M. Boztepe, M.C olak, Neural network based solar cell model, Energy Conversion and Management, 47(9), pp.1159-1178, 2006.

[19] A. Rezvani , M. Gandomkar, M. Izadbakhsh and S. Vafaei .Optimal power tracker for photovoltaic system using ann-ga. International Journal of Current Life Sciences, 4(9), pp 107-111, 2014.

[20] A. A.Kulaksız, ve R. Akkaya, Training Data Optimization for ANNs using Genetic Algorithms to Enhance MPPT Efficiencyof a Stand-alone PV System, Turkish Journal of Electrical Engineering \& Computer Sciences, 20(2), pp.241-254,2012.

[21] R.Ramaprabha and B L Mathur. " Intelligent Controller based Maximum Power Point Tracking for Solar PV System", International Journal of Computer Applications" 12(10), pp.37-41,2011.

[22] J. Yang, V. Honavar, Feature subset selection using a genetic algorithm, IEEE Intelligent Systems,. 13(2), pp.44-49, 1998.

[23] F. Blaabjerg, R. Teodorescu, M. Liserre, A. V. Tim-bus, Overview of Control and Grid Synchronization for Distributed Power Generation Systems, IEEE Transactions on Industrial Electronics, 53(5) , pp.1398-1409, 2006.

\section{Authors}

AlirezaRezvaniwas born in Tehran, Iran in 1989. Hereceived his B.Sc and M.Sc degrees in electrical power engineering from Islamic Azad University,Saveh Branch, Iran in 2011 and 2014, respectively. His research interests include the renewable energy, microgrid,Power system planning and operation, hybrid systemand optimization.

MajidGandomkar was born in the Saveh, Iran. He received PHD degree of Electrical Engineering from Science and Research Branch of Islamic Azad University. His research interests include distribution systems, DG systems, optimization. Now, he is Assistant Professor at Islamic Azad University, Saveh Branch.

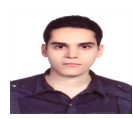

MaziarIzadbakhshwas born in Tehran, Iran in 1989. Hereceived his B.Sc and M.Sc degrees in electrical power engineering from Islamic Azad University,Saveh Branch, Iran in 2011 and 2014, respectively. His research interests include the renewable energy, microgrid, Power system planning and operation, hybrid systemand optimization
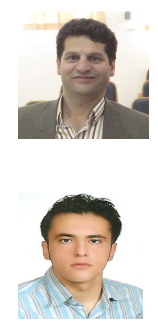